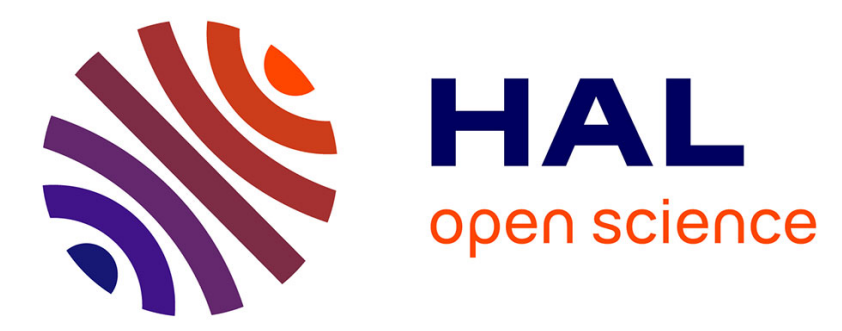

\title{
The effect of temperature and heating rate on char properties obtained from solar pyrolysis of beech wood
}

Kuo Zeng, Doan Pham Minh, Daniel Gauthier, Elsa Weiss-Hortala, Ange

Nzihou, Gilles Flamant

\section{- To cite this version:}

Kuo Zeng, Doan Pham Minh, Daniel Gauthier, Elsa Weiss-Hortala, Ange Nzihou, et al.. The effect of temperature and heating rate on char properties obtained from solar pyrolysis of beech wood. Bioresource Technology, 2015, 182, p.114-119. 10.1016/j.biortech.2015.01.112 . hal-01176348

\section{HAL Id: hal-01176348 \\ https://hal-univ-perp.archives-ouvertes.fr/hal-01176348}

Submitted on 4 May 2018

HAL is a multi-disciplinary open access archive for the deposit and dissemination of scientific research documents, whether they are published or not. The documents may come from teaching and research institutions in France or abroad, or from public or private research centers.
L'archive ouverte pluridisciplinaire HAL, est destinée au dépôt et à la diffusion de documents scientifiques de niveau recherche, publiés ou non, émanant des établissements d'enseignement et de recherche français ou étrangers, des laboratoires publics ou privés. 


\title{
The effect of temperature and heating rate on char properties obtained from solar pyrolysis of beech wood
}

\author{
Kuo Zeng ${ }^{\mathrm{a}}$, Doan Pham Minh ${ }^{\mathrm{b}}$, Daniel Gauthier ${ }^{\mathrm{a}}$, Elsa Weiss-Hortala ${ }^{\mathrm{b}}$, Ange Nzihou ${ }^{\mathrm{b}}$, Gilles Flamant ${ }^{\mathrm{a}, *}$ \\ ${ }^{a}$ Processes, Materials and Solar Energy Laboratory, PROMES-CNRS, 7 rue du Four Solaire, 66120 Font Romeu, France \\ ${ }^{\mathrm{b}}$ Université de Toulouse, Mines Albi, UMR CNRS 5302, Centre RAPSODEE, Campus Jarlard, F-81013 Albi Cedex 09, France
}

\section{H I G H L I G H T S}

- Char was obtained during solar pyrolysis at various temperatures and heating rates.

- "Solar chars" up to $2000{ }^{\circ} \mathrm{C}$ and up to $450{ }^{\circ} \mathrm{C} / \mathrm{s}$ have been produced.

- Temperature and heating rate jointly affected char yield, structure and reactivity.

- Reactivity evolution with temperature and heating rate were related to structure.

\section{A B S T R A C T}

Char samples were produced from pyrolysis in a lab-scale solar reactor. The pyrolysis of beech wood was carried out at temperatures ranging from 600 to $2000^{\circ} \mathrm{C}$, with heating rates from 5 to $450^{\circ} \mathrm{C} / \mathrm{s}$. CHNS, scanning electron microscopy analysis, X-ray diffractometry, Brunauer-Emmett-Teller adsorption were employed to investigate the effect of temperature and heating rate on char composition and structure. The results indicated that char structure was more and more ordered with temperature increase and heating rate decrease (higher than $50^{\circ} \mathrm{C} / \mathrm{s}$ ). The surface area and pore volume firstly increased with temperature and reached maximum at $1200^{\circ} \mathrm{C}$ then reduced significantly at $2000^{\circ} \mathrm{C}$. Besides, they firstly increased with heating rate and then decreased slightly at heating rate of $450{ }^{\circ} \mathrm{C} / \mathrm{s}$ when final temperature was no lower than $1200^{\circ} \mathrm{C}$. Char reactivity measured by TGA analysis was found to correlate with the evolution of char surface area and pore volume with temperature and heating rate.

Keywords:

Beech wood

Solar pyrolysis

Char structure

Reactivity

Combined effect

\section{Introduction}

Biomass is a renewable energy source that can partly relieve the energy crisis and environmental problems. Then the technology converting biomass effectively and efficiently into fuel and chemical stock receives more and more attention. Pyrolysis is one of the most attractive processes to convert biomass into economically renewable intermediates (Mettler et al., 2012). As pyrolysis is an endothermic thermochemical process, external heat is required. In standard pyrolysis, the heat is obtained by combustion of fossil fuel or of part of the initial biomass, which reduces the energy efficiency and increases the pollution discharge (Nzihou et al., 2012). For avoiding the disadvantage of standard pyrolysis, concentrated solar energy can be used to provide the heat for pyrolysis reactions. The biomass directly absorbs the heat from concentrated solar

\footnotetext{
* Corresponding author. Tel.: +33 4 68307758; fax: +33468307799. E-mail address: gilles.flamant@promes.cnrs.fr (G. Flamant).
}

energy thus resulting in fast or rapid pyrolysis, producing gases, tar and char.

The char is carbon-rich and can be further used as a fuel (gasification and combustion) or decontamination adsorbent. Firstly, it is necessary to understand the char reactivity for designing a high efficiency gasification or combustion reactor (Cetin et al., 2005). Secondly, the appropriate pore structure and surface area are important for preparing decontamination adsorbent (Demirbas et al., 2006). For making better use of char obtained from solar pyrolysis, the composition, surface area, pore structure and reactivity should be investigated in advance. Char reactivity and morphological structure are especially affected by the pyrolysis conditions (Blasi, 2009; Raveendran and Ganesh, 1998). The effects of pyrolysis conditions on the structure and reactivity of biomass chars have been investigated in several studies in relation to the following parameters: temperature (Fu et al., 2012a, 2011; Kim et al., 2012; Min et al., 2011; Bonelli et al., 2001), heating rate (Mermoud et al., 2006; Guerrero et al., 2005; Fushimi et al., 2003), residence time and pressure (Cetin et al., 2005, 2004). 
The char carbon content increases with temperature, which is the indication of increased structure ordering for lowering the reaction site concentration (Kumar and Gupta, 1994). The char surface area increases with temperature and then slightly decreases when the temperature is higher than $1173 \mathrm{~K}$ (Fu et al., 2012b). There is a significant diminution in char reactivity with the increase of temperature (above $1073 \mathrm{~K}$ ) as previously reported (Guerrero et al., 2005; Chen et al., 1997). At lower temperature (below $1073 \mathrm{~K}$ ), the release of volatile intensifies owing to the temperature increase enlarges the char surface area. However, there are more and more structural ordering and micropore coalescence for char when temperature keeps on increasing even higher than $1073 \mathrm{~K}$.

The increase of heating rate causes a weak decrease in the carbon content and an increase in hydrogen and oxygen content of char. Moreover, the heating rate effect tends to disappear at high temperatures (Antal and Grønli, 2003). The presence of higher hydrogen and oxygen contents is related to the availability of active sites and thus to enhanced reactivity (Laurendeau, 2009). For slow heating rates (lower than $1^{\circ} \mathrm{C} / \mathrm{s}$ ), no major change takes place in the particle morphology as volatile is released through the natural porosity (Della Rocca et al., 1999). For fast heating rates (higher than $10^{\circ} \mathrm{C} / \mathrm{s}$ ), the original cellular structure is lost as a consequence of melting (Kurosaki et al., 2003). When the heating rate increases, the volatile release speeds up. Then large internal cavities and a more open structure of char is produced (Guerrero et al., 2005) owing to the fast volatile release producing internal overpressure and coalescence of the smaller pores, which leads to the increase of surface area and pore volume. So the char reactivity increases with heating rate can be explained by the higher surface area and pore volume (Cetin et al., 2005, 2004). Besides, heating rate rising shortens tar vapors residence time in pores and reduces the condensation reaction leading to char reactivity increase (Kurosaki et al., 2003). However, char obtained at high heating rate has lower surface area compared to that at low heating rate when temperature was $900{ }^{\circ} \mathrm{C}$ (Fu et al., $2012 \mathrm{~b}$ ). It is attributed to too high heating rate causing char interior higher temperature, a partial graphitization with formation of grapheme structure occurs, which does not contribute to the development of large surface area.
Almost all of the above conclusions have been deduced from univariable analysis. However, there is little information on the char prepared at different pyrolysis temperatures with different heating rates (Angin, 2013; Fu et al., 2012b). In this study, the bivariate analysis was used for investigating the combined effect of pyrolysis temperature and heating rate on char characteristics. Besides, there are two characteristics for the solar reactor that may affect char characteristics: (1) High temperature and heating rate can be achieved; (2) Two temperature zones exist as described in Ref. Hopkins et al. (1984) and modeled in Ref. Zeng et al. (2014a). Indeed, since only the sample is directly heated by solar radiation, the "hot" sample is surrounded by relatively "cold" gas. Then, most vapors issued from primary reactions are quenched as soon as they leave the sample. Then the evaluation of char obtained in two temperature zones reactor at high temperature (up to $2000^{\circ} \mathrm{C}$ ) and high heating rate (up to $450{ }^{\circ} \mathrm{C} / \mathrm{s}$ ) is investigated for the first time. The purpose of this paper was to: (i) characterize the structure and composition of chars generated under different pyrolysis conditions; (ii) study the reactivity of char prepared at different temperatures and heating rates; (iii) relate the characterization and reactivity for the char.

\section{Experimental}

\subsection{Materials}

Beech wood pellets were used for pyrolysis experiments. The initial sawdust particle size ranged from 0.35 to $0.80 \mathrm{~mm}$. After sawdust compaction, the pellets were cylinders with $10 \mathrm{~mm}$ in diameter and $5 \mathrm{~mm}$ thick. The proximate analysis of beech wood is $85.3 \%$ volatile matter, $14.3 \%$ fixed carbon, $0.4 \%$ ash and $6 \%$ moisture. The ultimate analysis for beech wood is as follows: $\mathrm{C}=50.8 \%$, $\mathrm{H}=5.9 \%, \mathrm{O}=42.9 \%, \mathrm{~N}=0.3 \%$ and $\mathrm{S}=0.02 \%$.

\subsection{Pyrolysis experiments}

\subsubsection{Solar reactor}

As shown in Fig. 1, pyrolysis experiments were carried out under an argon flow in a transparent Pyrex balloon reactor (inside

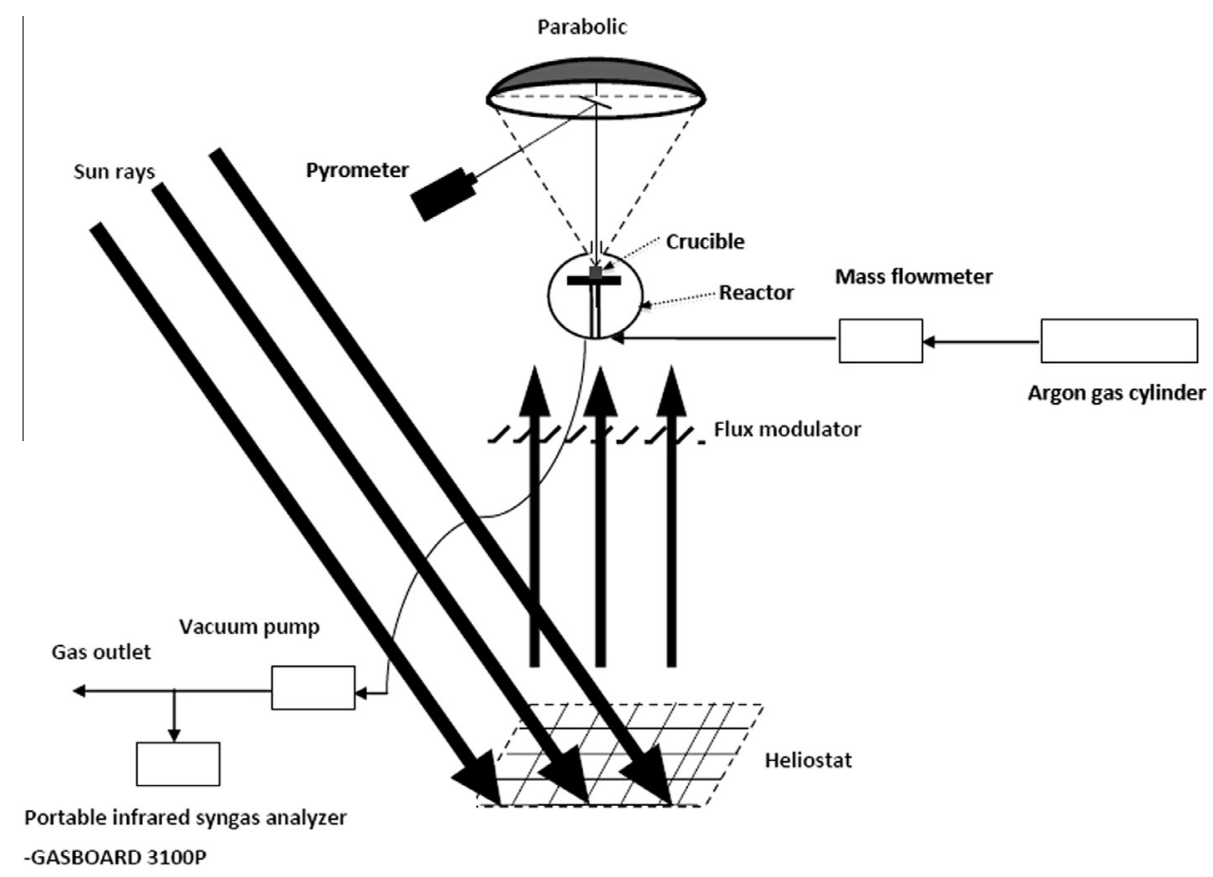

Fig. 1. Schematic of the solar pyrolysis experimental setup. 
diameter $185 \mathrm{~mm}$, volume $6 \mathrm{~L}$ ). The pellet was placed in a graphite crucible insulated with black foam and located at the focus of a $1.5 \mathrm{~kW}$ vertical-axis solar furnace. The sample surface temperature was measured by a solar-blind optical pyrometer (KLEIBER monochromatic at $5.2 \mu \mathrm{m}$ ). A shutter controlled by a PID controller modulated the incident radiation and thus mastered the sample temperature, e.g. the heating rate and the final temperature. Gas products mixed with argon were taken out by a vacuum pump through the gas outlet located on reactor bottom.

\subsubsection{Experimental procedure}

Pyrolysis experiments were performed under argon flow rate of $6 \mathrm{NL} / \mathrm{min}$. First, experiments were performed at four heating rates of $5,50,150$ and $450^{\circ} \mathrm{C} / \mathrm{s}$ to the final temperatures of 800,1200 and $2000{ }^{\circ} \mathrm{C}$. Afterwards, two other temperatures of $600{ }^{\circ} \mathrm{C}$ and $1600^{\circ} \mathrm{C}$ with the heating rate of $50^{\circ} \mathrm{C} / \mathrm{s}$ were used for pyrolysis experiments. All experiments were maintained at pyrolysis temperature for $6 \mathrm{~min}$. The temperature control results have been described in details in Ref. Zeng et al. (2014b). The real heating rates and final temperatures were approximated to the set values, which indicated that the temperature control system was accurate enough for experiments.

Each experiment was repeated at least 3 times to check the repeatability. After each pyrolysis experiment, the char residue was kept in the solar reactor until it cooled to the room temperature. After weighting for determining the yield, the char was stored in desiccator to prevent moisture absorption.

\subsubsection{Char characterization}

The elemental composition of char (CHNS) was determined by NA 2100 protein. Surface morphology was investigated by scanning electron microscopy (Philips XL30 FEG). XRD analysis was performed at room temperature using a PANalytical XPert Pro diffractometer (CuK radiation, $\lambda=0.15418 \mathrm{~nm}, 40 \mathrm{kV}-20 \mathrm{~mA}$ ). The surface area and pore volume were observed by BrunauerEmmeet-Teller (BET Tristar II 3020 Micromeritics). The reactivity measurements were performed under isothermal conditions using thermogravimetric analyzer (TG-DSC 111 Setaram). In TGA experiments, $20 \mathrm{~mL} / \mathrm{min}$ of nitrogen was used during the heating up period with the heating rate of $20^{\circ} \mathrm{C} / \mathrm{min}$ from room temperature to $800^{\circ} \mathrm{C}$. After that, the sweeping gas was switched on to the air for starting the oxidation reaction. The total gas flow rate was $2 \mathrm{~L} / \mathrm{h}$ with $20 \%$ oxygen ratio. The experiment was finished when the weight loss decreased close to zero.

\section{Results and discussion}

\subsection{The effect of temperature and heating rate on char yield and composition}

\subsubsection{The effect on char yield}

The yields of char prepared at different final temperatures and heating rates are shown in Table 1 . The char yields decreased with temperature and heating rate, which may be due to the primary or greater secondary decomposition of char (Şensöz and Angin, 2008). The char yield reduction rate with temperature was $0.004 \% /{ }^{\circ} \mathrm{C}$ (heating rate of $50{ }^{\circ} \mathrm{C} / \mathrm{s}$ ). It increased to $0.011 \% /{ }^{\circ} \mathrm{C} / \mathrm{s}$ (temperature of $1200^{\circ} \mathrm{C}$ ). Then, the influence of heating rate on the char yield was more obvious than that of temperature. When the heating rate was high enough, there was no big difference of char yield produced at 150 and $450{ }^{\circ} \mathrm{C} / \mathrm{s}$ at the same temperature. The char yield reduction rates with heating rate were $0.0090,0.0112$ and $0.0115 \% /{ }^{\circ} \mathrm{C} / \mathrm{s}$, respectively for temperature: 800,1200 and $2000^{\circ} \mathrm{C}$. So the effect of heating rate on char yield was more significant at high temperature. With the low heating rate of $5^{\circ} \mathrm{C} / \mathrm{s}$, the
Table 1

Effect of pyrolysis temperature and heating rate on char yield.

\begin{tabular}{llllll}
\hline \multicolumn{5}{c}{ Pyrolysis temperature $\left({ }^{\circ} \mathrm{C}\right)$} \\
\cline { 2 - 5 } & 600 & 800 & 1200 & 1600 & 2000 \\
\hline $\begin{array}{c}\text { Heating rate } 5{ }^{\circ} \mathrm{C} / \mathrm{s} \\
\text { Yield (wt.\%) } \\
\text { Heating rate } 50{ }^{\circ} \mathrm{C} / \mathrm{s} \\
\quad\end{array}$ & & $13.5 \pm 0.4$ & $13.4 \pm 0.1$ & - & $11.6 \pm 0.1$ \\
$\begin{array}{c}\text { Yield (wt.\%) } \\
\text { Heating rate } 150{ }^{\circ} \mathrm{C} / \mathrm{s} \\
\text { Yield (wt.\%) }\end{array}$ & $14.0 \pm 0.3$ & $12.5 \pm 0.2$ & $10.0 \pm 0.7$ & $8.3 \pm 0.4$ & $8.3 \pm 0.5$ \\
$\begin{array}{c}\text { Heating rate } 4500^{\circ} \mathrm{C} / \mathrm{s} \\
\text { Yield (wt.\%) }\end{array}$ & - & $9.7 \pm 0.1$ & $8.5 \pm 0.4$ & - & $7.2 \pm 0.2$ \\
\hline
\end{tabular}

char yields were almost the same at 800 and $1200{ }^{\circ} \mathrm{C}$. The highest char yield was about $14 \%$, which was obtained at $600^{\circ} \mathrm{C}$ with the heating rate of $50^{\circ} \mathrm{C} / \mathrm{s}$. The lowest char yield was about $6.5 \%$ when the temperature and heating rate were $2000^{\circ} \mathrm{C}$ and $450{ }^{\circ} \mathrm{C} / \mathrm{s}$, respectively. This trend could be explained by the release of volatiles and intermediate size organics lower at $600{ }^{\circ} \mathrm{C}$ than at higher temperatures investigated.

\subsubsection{The effect on char composition}

Table 2 gives the composition of char generated at different temperatures and heating rates. The carbon, hydrogen, nitrogen and sulfur were directly determined while oxygen was calculated by difference. Char was mainly composed of carbon with mass content higher than $75 \%$. When the temperature increased to $1600^{\circ} \mathrm{C}$, there was rapid growth of carbon content while the hydrogen and oxygen contents declined sharply. The char was completely carbonized with almost $100 \%$ carbon content at temperature of $2000^{\circ} \mathrm{C}$. The carbon content increase with temperature was assumed to come from the carbonaceous structure graphitization at high temperatures (Chen et al., 2012). Between 600 and $800^{\circ} \mathrm{C}$, the decrease for hydrogen and oxygen contents was most obvious, owing to the char weak bonds cracking and cleavage (Demirbas, 2004). There was no obvious effect of heating rate on char composition when temperature was higher than $800^{\circ} \mathrm{C}$, in accordance with what was mentioned before (Antal and Grønli, 2003).

\subsection{The effect of temperature and heating rate on char morphology and structure}

\subsubsection{SEM analysis}

Fig. S1 shows a comparison among SEM images of raw beech sawdust and its chars produced at different temperatures with the same heating rate of $50{ }^{\circ} \mathrm{C} / \mathrm{s}$. As can be seen from Fig. S1a, the raw wood made of solid cells was bounded together and there was almost no cavity. There were many small pores appearing in the char caused by devolatilization when the pyrolysis temperature was $800^{\circ} \mathrm{C}$ (Fig. S1b). However, the char was more and more twisted and rough with temperature rising, which meant that the deformation of char intensified with temperature increase up to $1200^{\circ} \mathrm{C}$ (Fig. S1C). This trend could be explained by the release of volatiles and intermediate size organics increasing with temperature. The cracks and pores in the chars increased with temperature increase, as observed previously (Fu et al., 2012b). When the temperature increased to $2000{ }^{\circ} \mathrm{C}$, the macropores disappeared owing to melting as illustrated in Fig. S1d. Small grains appeared as agglomeration of spherules in the char surface (Fig. S1c). Furthermore, the char particles present more and more growth filament crystals (Fig. S1d). The grains and the crystals observed on char surfaces may be inorganic compounds that have migrated to the surface.

The SEM images of char produced at different heating rates and same temperature of $1200{ }^{\circ} \mathrm{C}$ are shown in Fig. S2. There was no 
Table 2

Effect of pyrolysis temperature and heating rate on char composition.

\begin{tabular}{|c|c|c|c|c|c|}
\hline & \multicolumn{5}{|c|}{ Pyrolysis temperature $\left({ }^{\circ} \mathrm{C}\right)$} \\
\hline & 600 & 800 & 1200 & 1600 & 2000 \\
\hline \multicolumn{6}{|c|}{ Heating rate $5^{\circ} \mathrm{C} / \mathrm{s}$} \\
\hline C (wt.\%) & - & $82.7 \pm 0.7$ & $82.4 \pm 3.9$ & - & $99.8 \pm 0.3$ \\
\hline $\mathrm{H}(\mathrm{wt} . \%)$ & - & $2.0 \pm 0.2$ & $1.4 \pm 0.6$ & - & 0 \\
\hline $\mathrm{N}(\mathrm{wt} . \%)$ & - & $0.4 \pm 0.4$ & $0.2 \pm 0.3$ & - & 0 \\
\hline $\mathrm{O}$ (wt.\%) & - & $14.9 \pm 0.5$ & $16 \pm 3.1$ & - & $0.2 \pm 0.3$ \\
\hline \multicolumn{6}{|c|}{ Heating rate $50^{\circ} \mathrm{C} / \mathrm{s}$} \\
\hline C (wt.\%) & $76.4 \pm 3.3$ & $80.9 \pm 0.4$ & $82.3 \pm 0.5$ & $94.4 \pm 1.7$ & $99.8 \pm 0.7$ \\
\hline $\mathrm{H}(\mathrm{wt} . \%)$ & $2.6 \pm 0.2$ & $1.4 \pm 0.2$ & $1.0 \pm 0.2$ & 0 & 0 \\
\hline $\mathrm{N}(\mathrm{wt} . \%)$ & $0.3 \pm 0.3$ & $0.5 \pm 0.1$ & $0.6 \pm 0.1$ & 0 & 0 \\
\hline $\mathrm{O}$ (wt.\%) & $20.7 \pm 1.2$ & $17.2 \pm 0.3$ & $16.1 \pm 0.3$ & $5.6 \pm 1.7$ & $0.2 \pm 0.7$ \\
\hline \multicolumn{6}{|c|}{ Heating rate $150^{\circ} \mathrm{C} / \mathrm{s}$} \\
\hline C (wt.\%) & - & $82.4 \pm 0.4$ & $79.2 \pm 1.3$ & - & $99.7 \pm 0.4$ \\
\hline $\mathrm{H}(\mathrm{wt} . \%)$ & - & $2.1 \pm 0.2$ & $0.8 \pm 0.7$ & - & 0 \\
\hline $\mathrm{N}(\mathrm{wt} . \%)$ & - & $1.0 \pm 0.6$ & $0.8 \pm 0.1$ & - & 0 \\
\hline O (wt.\%) & - & $14.5 \pm 0.5$ & $19.2 \pm 1.2$ & - & $0.3 \pm 0.4$ \\
\hline \multicolumn{6}{|c|}{ Heating rate $450^{\circ} \mathrm{C} / \mathrm{s}$} \\
\hline C (wt.\%) & - & $82.5 \pm 0.1$ & $80.3 \pm 0.9$ & - & $99.8 \pm 0.8$ \\
\hline $\mathrm{H}(\mathrm{wt} . \%)$ & - & $1.8 \pm 0.2$ & $1.1 \pm 0.1$ & - & 0 \\
\hline $\mathrm{N}(\mathrm{wt} . \%)$ & - & $0.4 \pm 0.4$ & $0.7 \pm 0.1$ & - & 0 \\
\hline $\mathrm{O}$ (wt.\%) & - & $15.3 \pm 0.3$ & $17.9 \pm 0.7$ & - & $0.2 \pm 0.8$ \\
\hline
\end{tabular}

major morphological change from raw wood except the rough surface observed for the char obtained at the heating rate of $5{ }^{\circ} \mathrm{C} / \mathrm{s}$ (Fig. S2a). The char produced with the heating rate of $150^{\circ} \mathrm{C} / \mathrm{s}$ deformed a lot, with many open pores (Fig. S2c). However, char with few pores was observed when the heating rate increased to $450^{\circ} \mathrm{C} / \mathrm{s}$ (Fig. S2b). This may be due to high heating rate that resulted in plastic transformations and created smoother surfaces with spherical cavities (Cetin et al., 2004).

\subsubsection{XRD analysis}

The comparison of X-ray diffraction spectra of chars prepared at different heating rates and temperatures are shown in Fig. S3. The crystal plane indices $C(002)$ and $C(100)$ peak were present in the spectra, which correspond to $2 \theta$ values around $25^{\circ}$ and $45^{\circ}$. The degree of azimuthal orientation and parallel of the aromatic lamellae is represented by $\mathrm{C}(002)$. And $\mathrm{C}(100)$ reflects the aromatic lamina size. To investigate the temperature influence on char crystallinity, the heating rate was constant as $50^{\circ} \mathrm{C} / \mathrm{s}$. As the temperature increased from 800 to $1600^{\circ} \mathrm{C}$, the $\mathrm{C}(002)$ peak slightly sharpened. However, the $\mathrm{C}(002)$ peak greatly sharpened at temperature of $2000{ }^{\circ} \mathrm{C}$. Then the degree of orientation of aromatic lamellae increased with temperature especially at $2000{ }^{\circ} \mathrm{C}$ owing to the sharper $C(002)$ peak (Cui et al., 2006). The $C(100)$ peak was sharper and sharper when the temperature rose from 800 to $1600^{\circ} \mathrm{C}$. The sharp trend was very clear at $2000{ }^{\circ} \mathrm{C}$. And the higher the temperature, the higher the degree of condensation of the aromatic ring, as proved by the sharper C (100) peak (Cui et al., 2006). Two kinds of char obtained at different heating rates of 50 and $450^{\circ} \mathrm{C} / \mathrm{s}$ were compared to study the heating rate effect on crystallinity. It was found that the $\mathrm{C}(002)$ and $\mathrm{C}(100)$ peaks were sharper for char at $50^{\circ} \mathrm{C} / \mathrm{s}$ than those at $450^{\circ} \mathrm{C} / \mathrm{s}$. This proved that the char prepared at high heating rate had low crystallinity owing to melting (Cetin et al., 2004). With temperature increase and heating rate decrease (higher than $50^{\circ} \mathrm{C} /$ $\mathrm{s})$, the crystallinity increased, which indicated that the char structure was more and more ordered and aromatic.

\subsubsection{BET analysis}

The surface area and porosity of char were measured by means of $\mathrm{N}_{2}$ adsorption at $-196{ }^{\circ} \mathrm{C}$ on the TriStar II 3020. Table 3 shows the effect of temperature and heating rate on char textural properties. As can be seen from Table 3 , when the heating rate was $50^{\circ} \mathrm{C} /$ $\mathrm{s}$, the BET surface area increased from $70.2 \mathrm{~m}^{2} / \mathrm{g}$ to $110.2 \mathrm{~m}^{2} / \mathrm{g}$ with temperature increased from $800^{\circ} \mathrm{C}$ to $1200{ }^{\circ} \mathrm{C}$ then it decreased dramatically to $22.2 \mathrm{~m}^{2} / \mathrm{g}$ at $2000{ }^{\circ} \mathrm{C}$. The pore volume increased about 17 times with increasing temperatures from 800 to $1600^{\circ} \mathrm{C}$, then there was a slight decrease at $2000^{\circ} \mathrm{C}$. The result was similar to that reported in literature, which showed that the total surface area firstly increases with rising temperature lower than $900{ }^{\circ} \mathrm{C}$ and then decreases when the temperature keeps increasing (Fu et al., 2012b). When the temperature increases from 800 to $2000{ }^{\circ} \mathrm{C}$, there are two competing processes affecting the surface area: (1) Intensifying volatile release (Kim et al., 2012); (2) Thermal deactivation over $900{ }^{\circ} \mathrm{C}$ (Lu et al., 2002). The first process causes the increase of surface area and pore volume. The second process induces char melting, pore fuse and structure ordering leading to the decrease of surface area and pore volume. Based on these result, it was easily found that the first process defeated the second process and dominated with the temperature increase from 800 to $1200^{\circ} \mathrm{C}$. However, with temperature as high as $2000^{\circ} \mathrm{C}$, the second process seemed to be predominant causing the decrease of surface area and pore volume.

As depicted in Table 3, a gradual increase of the BET surface area and pore volume can be observed with heating rate peaking around $150^{\circ} \mathrm{C} / \mathrm{s}$. This may be due to the higher heating rates resulting in char particles melting and creation of smoother surfaces and spherical cavities (Cetin et al., 2004, 2005; Mohanty et al., 2013). Then there was a slight decrease when the heating rate increased to $450{ }^{\circ} \mathrm{C} / \mathrm{s}$. It may be explained by char interior partial graphitization caused by inner high temperature at too high heating rates (Fu et al., $2012 \mathrm{~b}$ ). Between $5{ }^{\circ} \mathrm{C} / \mathrm{s}$ and $50{ }^{\circ} \mathrm{C} / \mathrm{s}$, the BET surface area increased 14 -fold while the pore volume increased about 6 times. After that, the change was not so obvious. It showed the significant effect of fast heating rate on surface area and pore volume. Once the heating rate was equal to the flash heating rate, the influence was not so obvious. In addition, the surface area and pore volume increased about 1.27 and 1.15 times when the heating rate increased from $50^{\circ} \mathrm{C} / \mathrm{s}$ to $150{ }^{\circ} \mathrm{C} / \mathrm{s}$, at temperature $1200^{\circ} \mathrm{C}$. However, they increased about 3 and 2.5 times at $2000^{\circ} \mathrm{C}$. As the heating rate kept increasing to $450{ }^{\circ} \mathrm{C} / \mathrm{s}$, they decreased about 1.1 and 1.2 times at $1200^{\circ} \mathrm{C}$. Then, they decreased about 2 and 1.6 times when the temperature was $2000^{\circ} \mathrm{C}$. By comparing with the heating rate effect at temperatures of $1200{ }^{\circ} \mathrm{C}$ and $2000^{\circ} \mathrm{C}$, it was easily found that the heating rate effect on char surface area and pore volume was more remarkable at higher temperatures. 
Table 3

Effect of pyrolysis temperature and heating rate on char surface area and pore volume.

\begin{tabular}{|c|c|c|c|c|}
\hline & \multicolumn{4}{|c|}{ Pyrolysis temperature $\left({ }^{\circ} \mathrm{C}\right)$} \\
\hline & 800 & 1200 & 1600 & 2000 \\
\hline $\begin{array}{l}\text { Heating rate } 5^{\circ} \mathrm{C} / \mathrm{s} \\
\text { BET surface area }\left(\mathrm{m}^{2} / \mathrm{g}\right) \\
\text { BJH adsorption pore volume }\left(\mathrm{cm}^{3} / \mathrm{g}\right)\end{array}$ & $\begin{array}{l}- \\
-\end{array}$ & $\begin{array}{l}7.9 \\
0.0050\end{array}$ & $\begin{array}{l}- \\
-\end{array}$ & $\begin{array}{l}- \\
-\end{array}$ \\
\hline $\begin{array}{l}\text { Heating rate } 50{ }^{\circ} \mathrm{C} / \mathrm{s} \\
\text { BET surface area }\left(\mathrm{m}^{2} / \mathrm{g}\right) \\
\text { BJH adsorption pore volume }\left(\mathrm{cm}^{3} / \mathrm{g}\right)\end{array}$ & $\begin{array}{l}70.2 \\
0.0028\end{array}$ & $\begin{array}{r}110.2 \\
0.0470\end{array}$ & $\begin{array}{l}48.7 \\
0.0400\end{array}$ & $\begin{array}{l}22.2 \\
0.0323\end{array}$ \\
\hline $\begin{array}{l}\text { Heating rate } 1500^{\circ} \mathrm{C} / \mathrm{s} \\
\text { BET surface area }\left(\mathrm{m}^{2} / \mathrm{g}\right) \\
\text { BJH adsorption pore volume }\left(\mathrm{cm}^{3} / \mathrm{g}\right)\end{array}$ & - & $\begin{array}{r}140.8 \\
0.0540\end{array}$ & - & $\begin{array}{l}60.3 \\
0.0790\end{array}$ \\
\hline $\begin{array}{l}\text { Heating rate } 4500^{\circ} \mathrm{C} / \mathrm{s} \\
\text { BET surface area }\left(\mathrm{m}^{2} / \mathrm{g}\right) \\
\text { BJH adsorption pore volume }\left(\mathrm{cm}^{3} / \mathrm{g}\right)\end{array}$ & $\begin{array}{l}- \\
-\end{array}$ & $\begin{array}{l}127.8 \\
0.0465\end{array}$ & $\begin{array}{l}- \\
-\end{array}$ & $\begin{array}{l}31.5 \\
0.0524\end{array}$ \\
\hline
\end{tabular}

\subsection{The effect of temperature and heating rate on char reactivity}

The reactivity often characterizes the oxidation or gasification rate, which refers to the evolution of carbonaceous solid mass loss at an instant with respect to its mass at this time, which can be calculated by using Eq. (1). The conversion degree expresses the degree of reaction advancement which can be written as Eq. (2).

$R(t)=-\frac{1}{m(t)} \frac{d m(t)}{d t}=-\frac{m_{2}-m_{1}}{\left(t_{2}-t_{1}\right) m_{1}}$

$X=\frac{m_{0}-m}{m_{0}}$

where $m$ is the instantaneous sample mass, $m_{0}$ the initial sample mass, $R(t)$ the reactivity at time $t, m_{1}$ the sample mass at $t_{1}$ time when weight measurement starts, $m_{2}$ the sample mass at $t_{2}$ time when the weight measurement ends. The conversion degree $(X=20 \%-80 \%)$ was selected as a representative reactivity value for each experiment.

The apparent reactivity values, at heating rate of $50^{\circ} \mathrm{C} / \mathrm{s}$, corresponding to air oxidation of chars generated at 800,1200,1600 and $2000^{\circ} \mathrm{C}$ have been plotted in Fig. 2. As shown in Fig. 2, the reactivity of char generated at $1200^{\circ} \mathrm{C}$ was the highest, whereas it was the lowest at $2000{ }^{\circ} \mathrm{C}$. And the reactivity of char produced at $800{ }^{\circ} \mathrm{C}$ was higher than those obtained at $1600^{\circ} \mathrm{C}$. This may be due to the highest surface area and pore volume produced at $1200^{\circ} \mathrm{C}$. According to the CHNS results, the carbon and hydrogen contents increased and decreased respectively with temperature, which was the indication of increased structure ordering. The increased structure ordering was the indication for lowering the reaction site concentration (Lu et al., 2002). It seemed that the char reactivity reduced with temperature if we used the carbon and hydrogen concentration as indicator for reactivity. Indeed, the surface area and pore volume were more appropriate and accurate for reactivity evaluation. Besides, there was no big difference of reactivity for the chars at various high temperatures. For example, the reactivity of char obtained at $1200^{\circ} \mathrm{C}$ was about $21 \%$ higher than that at $2000{ }^{\circ} \mathrm{C}$. It was probably due to char structure ordering occurring at all these high temperatures.

The apparent reactivity values for chars prepared at temperatures of 1200 and $800^{\circ} \mathrm{C}$ corresponding to different heating rates $\left(5,50,150\right.$ and $\left.450^{\circ} \mathrm{C} / \mathrm{s}\right)$ have been illustrated, respectively in Fig. 3 and Fig. 4. As can be seen from Fig. 3, the reactivity increased with heating from 5 to $150^{\circ} \mathrm{C} / \mathrm{s}$. This could be due to the higher surface areas for char generated at higher heating rates (Cetin et al., 2005). And then it slightly decreased at the heating rate $450^{\circ} \mathrm{C} / \mathrm{s}$ when the temperature was $1200^{\circ} \mathrm{C}$. This may be due to the interior partial graphitization with too high heating rate $(\mathrm{Fu}$ et al., 2012b). Fig. 3 shows the reactivity of char obtained at heating

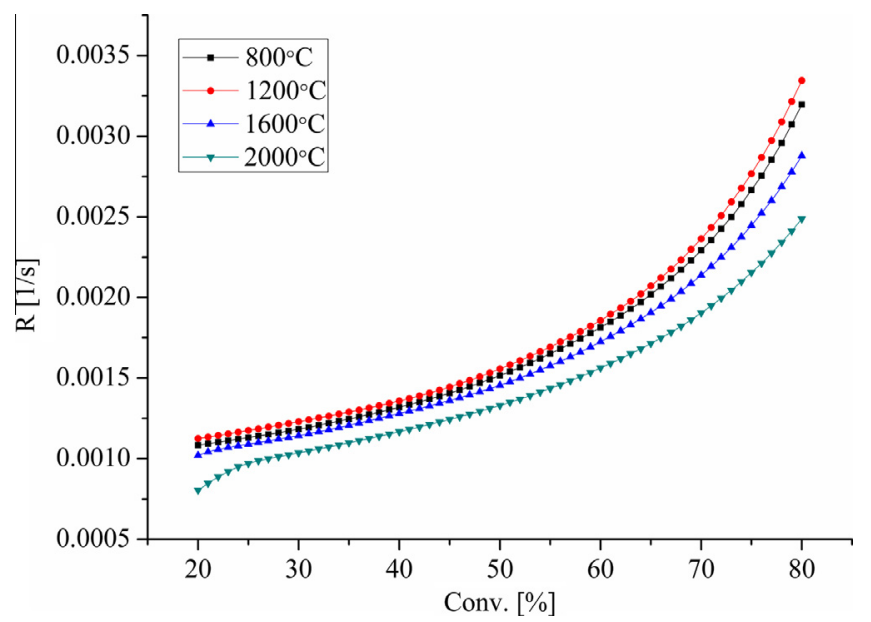

Fig. 2. Temperature effect on char reactivity, prepared at same heating rate $\left(50^{\circ} \mathrm{C} / \mathrm{s}\right)$.

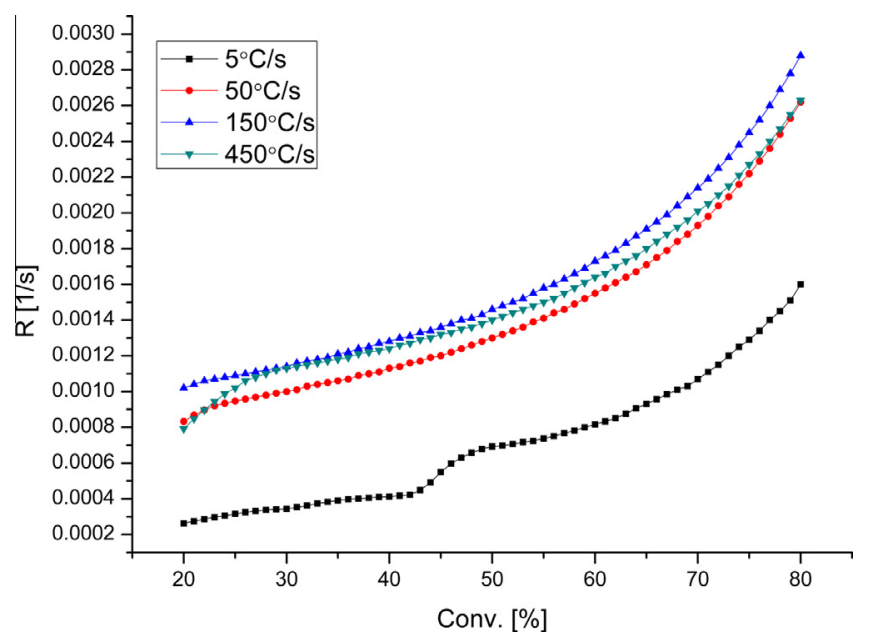

Fig. 3. Heating rate effect on char reactivity, prepared at $1200^{\circ} \mathrm{C}$.

rate $5^{\circ} \mathrm{C} / \mathrm{s}$ was much lower than those at higher heating rates. For example, chars generated at $150^{\circ} \mathrm{C} / \mathrm{s}$ had much higher reactivity (approx. 2.3 times) than those at $5^{\circ} \mathrm{C} / \mathrm{s}$. However, the char reactivity kept on increasing with heating rate from 5 to $450^{\circ} \mathrm{C} / \mathrm{s}$ at temperature of $800{ }^{\circ} \mathrm{C}$ (Fig. 4). This was because the fast volatile release produces internal overpressure and coalescence of the smaller pores, leading to surface area and pore volume increase with heating rate (Guerrero et al., 2005). Another reason was that the tem- 


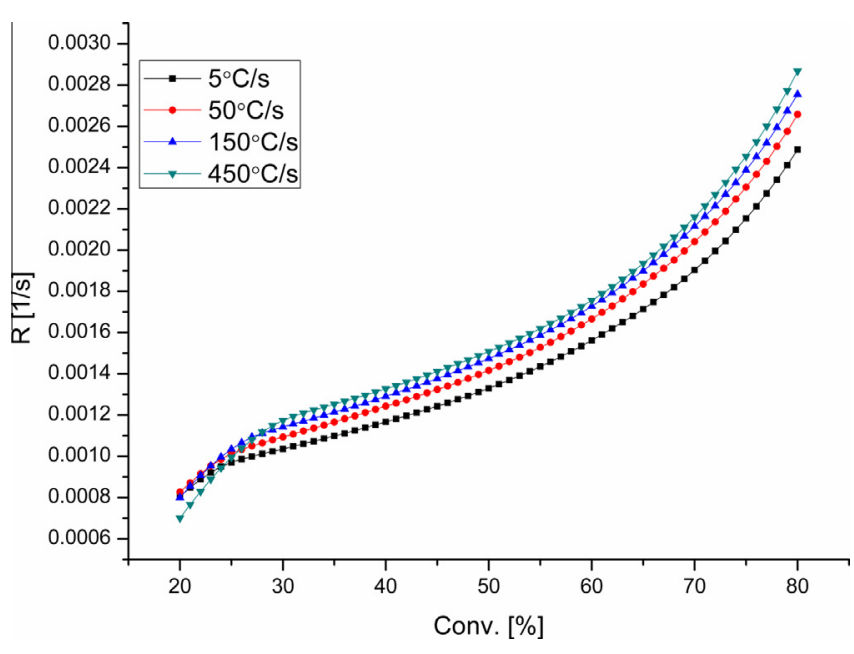

Fig. 4. Heating rate effect on char reactivity, prepared at $800{ }^{\circ} \mathrm{C}$.

perature was not high enough (lower than $1200^{\circ} \mathrm{C}$ ) for char interior partial graphitization even with high heating rate as $450^{\circ} \mathrm{C} /$ $\mathrm{s}$. At first glance, the shape of char obtained at $5^{\circ} \mathrm{C} / \mathrm{s}$ was pellet, which had more compact structure with smaller surface area. Char produced at higher heating rates $\left(50,150\right.$ and $\left.450{ }^{\circ} \mathrm{C} / \mathrm{s}\right)$ were noncompact powder, which had bigger surface area and pore volume. Then the lower reactivity at lower heating rate can be attributed to the smaller surface area and pore volume with respect to the high heating rate (Cetin et al., 2004, 2005; Mohanty et al., 2013).

\section{Conclusion}

Char properties were influenced by solar pyrolysis temperature and heating rate. The char yield decreased with temperature and heating rate. Char carbonized degree increased with temperature increase and heating rate decrease (higher than $50^{\circ} \mathrm{C} / \mathrm{s}$ ). The BET surface area and pore volume firstly increased with rising temperature from 800 to $1200^{\circ} \mathrm{C}$, then decreased at higher temperatures. They firstly increased with heating rate peak around $150{ }^{\circ} \mathrm{C} / \mathrm{s}$ and then decreased at $450^{\circ} \mathrm{C} / \mathrm{s}$ when temperature was no lower than $1200^{\circ} \mathrm{C}$. The bigger the BET surface area and pore volume, the higher the char reactivity, which means that they are good indicators for char reactivity.

\section{Acknowledgements}

This work was supported by French "Investments for the future" programme managed by the National Agency for Research under contract ANR-10-LABX-22-01.

Authors thank Eric Bèche and Danielle Pérarnau (PROMESCNRS) for XRD measurements.

\section{Appendix A. Supplementary data}

Supplementary data associated with this article can be found, in the online version, at http://dx.doi.org/10.1016/j.biortech.2015.01. 112.

\section{References}

Angin, D., 2013. Effect of pyrolysis temperature and heating rate on biochar obtained from pyrolysis of safflower seed press cake. Bioresour. Technol. 128, 593-597.

Antal, M.J., Grønli, M., 2003. The art, science and technology of charcoal production. Ind. Eng. Chem. Res. 42, 1619-1640.
Blasi, C.D., 2009. Combustion and gasification rates of lignocellulosic chars. Prog. Energy Combust. Sci. 35, 121-140.

Bonelli, P.R., Della Rocca, P.A., Cerrella, E.G., Cukierman, A.L., 2001. Effect of pyrolysis temperature on composition, surface properties and thermal degradation rates of Brazil nut shells. Bioresour. Technol. 76, 15-22.

Cetin, E., Moghtaderi, B., Gupta, R., Wall, T.F., 2004. Influence of pyrolysis conditions on the structure and gasification reactivity of biomass chars. Fuel 83, 21392150.

Cetin, E., Gupta, R., Moghtaderi, B., 2005. Effect of pyrolysis pressure and heating rate on radiata pine char structure and apparent gasification reactivity. Fuel 84, $1328-1334$.

Chen, G., Yu, Q., Sjostrom, K., 1997. Reactivity of char from pyrolysis of birch wood. J. Anal. Appl. Pyrolysis 40, 491-499.

Chen, Y., Yang, H., Wang, X., Zhang, S., Chen, H., 2012. Biomass-based pyrolytic polygeneration system on cotton stalk pyrolysis: influence of temperature. Bioresour. Technol. 107, 411-418.

Cui, Z.Z., Li, D.C., Qiao, G.J., Li, J.S., 2006. Preparation of porous carbon template with controllable channels by phenolic resin pyrolyzing. J. Inorg. Mater. 21, 848-854.

Della Rocca, P.A., Cerrella, E.G., Bonelli, P.R., Cuckierman, A.L., 1999. Pyrolysis of hard-woods residues: on kinetics and char characterization. Biomass Bioenergy $16,79-88$.

Demirbas, A., 2004. Effects of temperature and particle size on bio-char yield from pyrolysis of agricultural residues. J. Anal. Appl. Pyrolysis 72, 243-248.

Demirbas, A., Pehlivan, E., Altun, T., 2006. Potential evolution of Turkish agricultural residues as bio-gas, bio-char and bio-oil sources. Int. J. Hydrogen Energy 31, 613-620.

Fu, P., Yi, W.M., Bai, X.Y., Li, Z.H., Hu, S., Xiang, J., 2011. Effect of temperature on gas composition and char structural features of pyrolyzed agricultural residues. Bioresour. Technol. 102, 8211-8219.

Fu, P., Hu, S., Xiang, J., Sun, L.S., Su, S., An, S.M., 2012a. Study on the gas evolution and char structural change during pyrolysis of cotton stalk. J. Anal. Appl. Pyrolysis 97, 130-136.

Fu, P., Hu, S., Xiang, J., Sun, L.S., Su, S., Wang, J., 2012b. Evaluation of the porous structure development of chars from pyrolysis of rice straw: effects of pyrolysis temperature and heating rate. J. Anal. Appl. Pyrolysis 98, 177-183.

Fushimi, C., Araki, K., Yamaguchi, Y., Tsutsumi, A., 2003. Effect of heating rate on steam gasification of biomass. 1. Reactivity of char. Ind. Eng. Chem. Res. 42, 3922-3928.

Guerrero, M., Ruiz, M.P., Alzueta, M.U., Bilbao, R., Millera, A., 2005. Pyrolysis of eucalyptus at different heating rates: studies of char characterization on oxidation reactivity. J. Anal. Appl. Pyrolysis 74, 307-314.

Hopkins, M.W., Dejenga, C., Antal, M.J., 1984. The flash pyrolysis of cellulosic materials using concentrated visible light. Sol. Energy 32, 547-551.

Kim, K.H., Kim, J.Y., Cho, T.S., Choi, J.W., 2012. Influence of pyrolysis temperature on physicochemical properties of biochar obtained from the fast pyrolysis of pitch pine (Pinus rigida). Bioresour. Technol. 118, 158-162.

Kumar, M., Gupta, R.C., 1994. Influence of carbonization conditions on the gasification acacia and eucalyptus wood chars by carbon dioxide. Fuel 73 , 1922-1925.

Kurosaki, F., Ishimaru, K., Hata, T., Bronsveld, P., Kobayashi, E., Imamura, Y., 2003. Microstructure of wood charcoal prepared by flash heating. Carbon 41, 3057 3062.

Laurendeau, N.M., 2009. Heterogeneous kinetics of coal char gasification and combustion. Prog. Energy Combust. Sci. 35, 121-140.

Lu, L.M., Kong, C.H., Sahajwallab, V., Harris, D., 2002. Char structure ordering during pyrolysis and combustion and its influence of char reactivity. Fuel 81, 12151225.

Mermoud, F., Salvador, S., Van de steene, L., Golfier, F., 2006. Influence of the pyrolysis heating rate on the steam gasification of large wood char particle. Fuel $85,1473-1482$

Mettler, M.S., Vlachos, D.G., Dauenhauer, P.J., 2012. Top ten fundamental challenges of biomass pyrolysis for biofuels. Energy Environ. Sci. 5, 7797-7890.

Min, F.F., Zhang, M.X., Zhang, Y., Cao, Y., Pan, W.P., 2011. An experimental investigation into the gasification reactivity and structure of agricultural waste chars. J. Anal. Appl. Pyrolysis 92, 250-257.

Mohanty, P., Nanda, S., Pant, K.K., Naik, S., Kozinski, J.A., Dalai, A.K., 2013. Evaluation of the physiochemical development of biochars obtained from pyrolysis of wheat straw, timothy grass and pinewood. J. Anal. Appl. Pyrolysis 104, 485-493.

Nzihou, A., Flamant, G., Stanmore, B., 2012. Synthetic fuels from biomass using concentrated solar energy - a review. Energy 42, 121-131.

Raveendran, K., Ganesh, A., 1998. Adsorption characteristics and pore-development of biomass-pyrolysis char. Fuel 77, 769-781.

Sensöz, S., Angin, D., 2008. Pyrolysis of safflower (Carthamus tinctorius L.) seed press cake: part 1. The effects of pyrolysis parameters on the product yields. Bioresour. Technol. 99, 5492-5497.

Zeng, K., Flamant, G., Gauthier, D., Guillot, E., 2014a. Solar pyrolysis of wood in a labscale solar reactor: influence of temperature and sweep gas flow rate on products distribution. In: Proceedings of the International SolarPACES Conference 2014. Beijing, China (September 16-19, 2014).

Zeng, K., Gauthier, D., Flamant, G., 2014b. High temperature flash pyrolysis of wood in a lab-scale solar reactor. In: Proceedings of ASME 2014 8th International Conference on Energy Sustainability. Boston, USA (June 30-July 2). 